\title{
UJI AKTIVITAS ANTIBAKTERI EKSTRAK ETANOL DAN FRAKSI BATANG KUNING (Fibraurea tinctoria Lour.) TERHADAP BAKTERI Escherichia coli dan Staphylococcus aureus
}

\author{
Lusi Mardika Ariyanti ${ }^{1)}$, Supomo ${ }^{{ }^{11}}$, Hayatus Sa'adah ${ }^{1)}$, Eka Siswanto Syamsul ${ }^{1)}$, Kintoko ${ }^{2)}$, \\ Hardi Astuti Witasari ${ }^{2)}$ \\ 1 Jurusan Farmasi, Sekolah Tinggi Ilmu Kesehatan Samarinda, Samarinda, Indonesia \\ 2 Fakultas Farmasi, Universitas Ahmad Dahlan, Yogyakarta, Indonesia \\ email: fahmipomo@gmail.com
}

\begin{abstract}
Abstrak
Akar kuning (Fibraurea tinctoria Lour.) merupakan tumbuhan khas yang dapat dijumpai di Kalimantan serta biasa dimanfaatkan oleh masyarakat setempat sebagai obat gatal, penyakit kuning dan diare. Salah satu senyawa kimia yang terkandung dalam akar kuning adalah berberin yang berpotensi memiliki khasiat sebagai antidiabetes, antivirus, antibakteri dan antiinflamasi. Penelitian ini bertujuan untuk mengetahui potensi tumbuhan Akar Kuning (Fibraurea tinctoria Lour.) sebagai antibakteri terhadap bakteri Escherichia coli dan Staphylococcus aureus dengan menggunakan metode disc diffusion. Ekstrak etanol difraksinasi dengan menggunakan pelarut n-heksan dan etilasetat, ekstrak dan fraksi yang telah didapat ditimbang dengan konsentrasi 2,5\%, 5\% dan 10\%. Kontrol positif yang digunakan yaitu amoxicillin dan DMSO sebagai kontrol negatif. Hasil penelitian menunjukkan bahwa ektrak etanol dan fraksi akar kuning (Fibraurea tinctoria Lour.) memiliki potensi untuk menghambat pertumbuhan bakteri. Aktivitas zona hambat terbesar yang terbentuk pada ekstrak etanol yaitu pada konsentrasi $10 \%$ dengan diameter zona hambat 9,18 mm terhadap bakteri Escherichia coli dan 12,16 mm terhadap bakteri Staphylococcus aureus sedangkan fraksi batang akar kuning yang memiliki aktivitas antibakteri paling kuat terhadap bakteri Escherichia coli dan Staphylococcus aureus yaitu fraksi sisa. Staphylococcus aureus memiliki sensitifitas lebih tinggi terhadap akar kuning (Fibraurea tinctoria Lour.) dari pada bakteri Escherichia coli.
\end{abstract}

Kata kunci : antibakteri, akar kuning, berberin, Fibraurea tinctoria Lour.

\begin{abstract}
Akar kuning (Fibraurea tinctoria Lour.) is typically plant that can be found in Kalimantan usually used by local people as itch medicine, jaundice and diarrhea. Berberin, one of the chemical compounds contained in the akar kuning, berberin has the potential to act as an anti-diabetic, antiviral, antibacterial, and anti-inflammatory. This study aimed to determine the activity of akar kuning as an antibacterial against Escherichia coli and Staphylococcus aureus using the disc diffusion method. Ethanol extract are fractionated using n-Heksan and Etilasetat solvents, the obtained of extract and fraction are weighed to 2,5\%,5\% and 10\%. Positive control antibacterial used amoxicillin and DMSO as negative control. The results showed that ethanol extracts and fraction of akar kuning (Fibraurea tinctoria Lour.) are have potential to inhibited bacteria growth. The highest antibacterial activity that showed at $10 \%$ concentration of ethanol extract with diameter inhibition is 9,18 mm to Escherichia coli and 12,16 mm to Staphylococcus aureus while the fraction of akar kuning which has the stronger antibacterial activity to Escherichia coli and Staphylococcus aureus is the rest fraction. Staphylococcus aureus were more susceptible to akar kuning (Fibraurea tinctoria Lour.) extract and fraction than Escherichia coli.
\end{abstract}

Keywords : antibacterial, akar kuning, berberin, Fibraurea tinctoria Lour.

\section{PENDAHULUAN}

Indonesia merupakan negara yang memiliki kawasan hutan yang cukup luas dan keanekaragaman hayati yang dapat diman-faatkan sebagai sumber daya alam bahan obat tradisional yang merupakan aset 
dan perlu digali, diteliti serta dikembangkan peman-faatannya (Tudjuka et al., 2014).

Selama berabad-abad berbagai kebudayaan di seluruh dunia telah mengenal, mempelajari dan memanfaatkan tumbuhan untuk pengobatan dan kesehatan (Petrovska, 2012). Demikian pula sejumlah suku yang mendiami wilayah Kalimantan seperti Suku Dayak, Kutai, Banjar, maupun Melayu juga memiliki pengetahuan tradisional yang mencakup sistem pengobatan tradisional dan penggunaan tumbuhan obat untuk kesehatan (Noorcahyati, n.d.). Pemerintah Republik Indonesia juga memberikan perhatian yang sangat besar menyangkut produk obat tradisional melalui program Saintifikasi Jamu sebagai upaya pemanfaatan kekayaan sumber daya hayati dan kekayaan kesehatan tradisional agar dapat terintegrasi dalam sistem kesehatan formal (Kesehatan, 2013).

Penyakit infeksi merupakan salah satu penyakit yang sering terjadi di negaranegara berkembang salah satunya Indonesia. Infeksi merupakan penyakit yang dapat ditularkan dari satu orang ke orang lain atau suatu hewan ke manusia. Infeksi ini biasa disebabkan oleh berbagai mikroorganisme antara lain bakteri, virus, riketsia, jamur dan protozoa (Fahdi et al., 2019). Pemberian antibiotik merupakan salah satu alternatif dalam pengobatan infeksi, akan tetapi jika penggunaan antibiotik yang tidak rasional akan menjadi sebab utama penyebaran resistensi secara global, sehingga terjadi bakteri yang multiresisten terhadap sekelompok antibiotik (Niasono et al., 2019). Oleh sebab itu untuk mengatasi resistensi antibiotik yang terbuat dari zat kimia diperlukan pengembangan antibiotik dari bahan alam yang cenderung memiliki resiko efek samping yang lebih rendah dibandingkan antibiotik sintetis.

Salah satu tumbuhan obat yang saat ini kian sulit ditemui di alam adalah batang kuning (Fibraurea tinctoria Lour.). beberapa masyarakat menyebutnya dengan akar kuning. Terdapat tiga spesies yang dikenal sebagai akar kuning, yaitu Arcangelisia flava, Coscinium fenestratum dan Fibraurea tinctoria. Dua jenis terakhir merupakan jenis yang banyak dimanfaatkan oleh etnis di Kalimantan sebagai obat tradisional seperti obat sakit kuning dan malaria. Pemanfaatan secara tradisional untuk pengobatan pada tumbuhan ini adalah bagian batangnya (Noorcahyati, n.d.).

Fibraurea tinctoria dan Coscinium fenestratum termasuk dalam keluarga Menispermaceae. Habitatnya berupa liana panjangnya mencapai 20 meter dan umumnya tumbuh secara liar di hutan sekunder atau semak belukar. Daerah sebarannya meliputi Sumatera, Kalimantan, Sulawesi, Halmahera, Filipina, Thailand, Indocina dan Malaya. Akar kuning dapat dijumpai pada ketinggian tempat yang beragam dari dataran rendah hingga ketinggian 1000 mdpl (Tan et al., 2020).

Pada penelitian ini digunakan jenis Fibraurea tinctoria untuk mengetahui potensinya sebagai antibakteri, karena penelitian terkait antibakteri belum banyak dilaporkan. Salah satu senyawa metabolit sekunder dari akar kuning yang potensial sebagai obat adalah berberin. Senyawa golongan alkaloid ini dilaporkan memiliki aktivitas antimikroba secara aktif terhadap bakteri gram positif maupun gram negatif (Kaharap et al., 2016).

Penelitian (Supomo et al., 2020) menyebutkan bahwa akar kuning (Fibraurea tinctoria) mengandung senyawa kimia antara lain alkaloid, flavonoid, tanin, saponin, steroid/triterpenoid. Hasil penelitian (Utami et al., 2017) akar kuning (Fibraurea tinctoria Lour) mengandung senyawa berberin $25,8 \%$. Senyawa berberin merupakan salah satu jenis alkaloid isoquinoline yang berfungsi sebagai antivirus, antibakteri dan juga sebagai antiinflamasi (Roy et al., 2018). Senyawa berberin yang terkandung pada batang akar kuning diyakini mampu mengatasi masalah resistensi yang terjadi akibat antibiotik sintetis, hal ini dapat dilihat dari hasil penelitian (Galappathie et al., 2014) bahwa ekstrak daun dan batang akar kuning memiliki kekuatan menghambat bakteri pada kategori sedang dengan konsentrasi ekstrak $400 \mu \mathrm{g} / \mathrm{disc}$ pada Bacillus cereus sebesar $10 \mathrm{~mm}$, sedangkan pada bakteri Staphylococcus aureus zona hambat yang terbentuk sebesar $10 \mathrm{~mm}$.

Penelitian sebelumnya menunjukkan bahwa ekstrak etanol akar kuning (Fibraurea tinctoria Lour.) memiliki aktivitas antibakteri terhadap bakteri Staphylococcus aureus dan Eschericia coli 
dengan nilai zona hambat $10 \mathrm{~mm}$ pada konsentrasi ekstrak etanol 10\% (Zalizar et al., 2019). Potensi akar kuning sebagai tumbuhan obat berbagai penyakit sangat besar untuk menjadi obat modern. Sampai saat ini pengembangan dan pemanfaatan tumbuhan ini sangat minim padahal manfaat tumbuhan ini sudah lama dirasakan masyarakat Kalimantan.

Berdasarkan uraian tersebut maka dilakukan penelitian terhadap ekstrak etanol dengan ekstraksi cair-cair menggunakan pelarut dengan kepolaran bertingkat, yaitu pelarut n-heksan dan etilasetat. Ekstrak etanol mengandung senyawa yang bersifat polar maupun semipolar sehingga masih bersifat ekstrak kasar, oleh karena itu perlu dilakukan fraksinasi untuk mendapatkan senyawa yang lebih spesifik berdasarkan tingkat kepolarannya. Tujuan dari penelitian ini adalah untuk mengetahui potensi ekstrak etanol dan fraksi batang akar kuning (Fibraurea tinctoria Lour.) sebagai antibakteri terhadap bakteri Escherichia coli dan Staphylococcus aureus.

\section{METODE PENELITIAN}

\section{Alat dan Bahan}

Alat yang digunakan dalam penelitian ini adalah alat-alat gelas $\left(\right.$ Pyrex $\left.^{\circledR}\right)$, blender $\left(\right.$ Maspion $\left.^{\circledR}\right)$, vortex, hotplate (IECR), cotton swap, sendok tanduk, pinset, kertas coklat, kertas cakram, lampu spiritus, autoclave $\left(\right.$ Isuzu $\left.^{\circledR}\right)$, incubator $\left(\right.$ Sanyo $\left.^{\circledR}\right)$, magnetic stirer, timbangan analitik (Ohaus ${ }^{\circledR}$ ), jangka sorong $\left(\right.$ Enzo $\left.^{\circledR}\right)$, penangas air, laminar airflow cabinet $\quad\left(\right.$ Streamline $\left.{ }^{\circledR}\right)$, spektrofotometer UV-Vis (Shimadzu $\left.{ }^{\circledR}\right)$.

Bahan yang digunakan dalam penelitian ini adalah batang akar kuning (Fibraurea tinctoria Lour), biakan bakteri Escherichia coli dan Staphylococcus aureus, aluminium foil, tissue, kapas steril, biakan bakteri, etanol $70 \%$, n-Heksan, etil asetat, nutrient agar, aquadest, kain kasa, tablet amoxicillin.

\section{Prosedur Kerja \\ Pembuatan Simplisia}

Batang akar kuning disortasi basah, dicuci dengan air mengalir, dikeringkan dengan cara diangin-anginkan terlindung dari sinar matahari langsung dan dilakukan perajangan (Supomo et al., 2020).

\section{Ekstraksi Batang Akar Kuning}

Pembuatan ekstrak batang akar kuning dilakukan dengan cara ditimbang 400 gram simplisia kemudian dilarutkan dengan $4 \mathrm{~L}$ etanol $70 \%$ pada wadah kaca didiamkan selama 3 hari dengan pengadukan sesekali. Maserat yang didapat diremaserasi dengan 2 L etanol $70 \%$. Kemudian hasil filtrat yang didapat dipekatkan dengan rotary evaporator dan dilakukan penangasan hingga diperoleh ekstrak kental (Mujipradhana et al., 2018).

\section{Fraksinasi}

Fraksinasi dilakukan dengan metode cair-cair, ditimbang 5 gram ekstrak kental dilarutkan dengan etanol 70\% dan air (1:1), selanjutnya difraksinasi dengan pelarut $n$ heksan dan etil asetat. Fraksinasi dilakukan secara bertahap pada masing-masing pelarut berdasarkan kelarutannya, ditangas hingga kental (Mujipradhana et al., 2018).

\section{Uji Aktivitas Antibakteri}

Uji aktivitas antibakteri dilakukan dengan metode difusi cakram. Bakteri $E$. coli dan $S$. aureus dilakukan peremajaan pada media NA. Biakan bakteri disuspensi dengan $\mathrm{NaCl}$ 0,9\% dan diukur kekeruhannya menggunakan spektrofotometer UV-Vis dengan range $75 \%$ pada panjang gelombang $600 \mathrm{~nm}$ dengan standar kekeruhan mac.farland .

Suspensi bakteri disweb pada media agar, kemudian kertas cakram steril yang telah direndam pada masing-masing sampel uji ekstrak batang akar kuning, fraksi nheksan, fraksi etil asetat dan fraksi sisa dengan konsentrasi 2,5\%, 5\%, dan 10\% serta kontrol positif dan negatif yaitu amoxicillin $0,1 \%$ dan DMSO $1 \%$ diletakkan di atas media agar. Selanjutnya diinkubasi pada suhu $37^{\circ} \mathrm{C}$ selama $24-48$ jam. Zona bening yang terbentuk disekitar kertas cakram dihitung dengan menggunakan jangka sorong dalam satuan milimeter (mm) (Mujipradhana et al., 2018).

\section{HASIL DAN PEMBAHASAN}

\section{Aktivitas Antibakteri}

Bakteri Escherichia coli dan Staphylococcus aureus merupakan bakteri patogen, dimana bakteri Escherichia coli 
merupakan bakteri yang dapat menyebabkan disentri, mual dan juga sakit perut, sedangkan bakteri Staphylococcus aureus merupakan bakteri yang dapat memicu terjadinya berbagai jenis infeksi mulai dari infeksi kulit ringan, keracunan makanan sampai dengan infeksi sistemik. Infeksi kulit yang dapat disebabkan oleh $S$. aureus yaitu impetigo, selulitis, folikulitis, dan abses. Beberapa infeksi yang tergolong berat yang disebabkan oleh $S$. aureus diantaranya Tabel 1. Hasil Uji Aktivitas Antibakteri Rata-rata Zona Hambat (mm) pneumonia, mastitis, infeksi saluran kemih, dan endokarditis. Staphylococcus aureus juga merupakan penyebab utama sindrom syok toksik (Rahmi et al., 2015).

Hasil uji aktivitas antibakteri ekstrak etanol dan fraksi batang akar kuning terhadap bakteri Escherichia coli dan Staphylococcus aureus dengan konsentrasi yang digunakan yaitu 2,5\%, 5\%, dan $10 \%$ dapat dilihat pada tabel 1 sebagai berikut:

\begin{tabular}{ccccc}
\hline \multirow{2}{*}{ Bakteri } & \multirow{2}{*}{ Perlakuan } & \multicolumn{3}{c}{ Rata-rata Diameter Zona Hambat (mm) } \\
& & $\mathbf{2 , 5 \%}$ & $\mathbf{5 \%}$ & $\mathbf{1 0 \%}$ \\
\hline \multirow{2}{*}{ E. coli } & Ekstrak & 6,96 & 7,11 & 9,18 \\
& n-Heksan & 7,2 & 7,22 & 6,79 \\
& Etilasetat & 7,44 & 8,76 & 7,83 \\
& Sisa & 9,03 & 9 & 10,16 \\
& Amo 0,1\% & & 16,75 & \\
& DMSO 1\% & & 0 & 12,16 \\
& Ekstrak & 8,21 & 8,95 & 7,96 \\
& n-Heksan & 7,06 & 6,64 & 7,83 \\
& Etilasetat & 7,20 & 7,37 & 11,09 \\
& Sisa & 10,3 & 13,71 & \\
& Amo 0,1\% & & 22,27 & 0 \\
\hline
\end{tabular}

Pada pengujian antibakteri seluruh variasi konsentrasi menunjukkan bahwa ekstrak dan fraksi batang akar kuning memiliki respon daya hambat yang sangat aktif terhadap pertum-buhan bakteri Eschericia coli dan Staphy-lococcus aureus. Berdasarkan hasil pengukuran zona hambat bakteri menunjukan bahwa bakteri Staphylococcus aureus yang merupa-kan jenis bakteri gram positif memiliki zona hambat yang lebih besar dari bakteri Escherichia coli, hal ini sesuai dengan hasil penelitian sebelumnya oleh (Galappathie et al., 2014) dan (Zalizar et al., 2019) bahwa ekstrak batang akar kuning memiliki aktivitas antibakteri lebih sensitif terhadap bakteri gram positif. Perbedaan zona hambat yang terbentuk pada uji aktivitas antibakteri dapat disebabkan oleh beberapa faktor yaitu adanya variasi konsentrasi sampel uji, semakin tinggi konsentrasi sampel maka zona hambat yang terbentuk akan semakin luas, suhu dan waktu inkubasi yang tidak optimal dapat menyebabkan difusi sampel uji kurang baik serta jenis pelarut yang digunakan dapat mempengaruhi jenis senyawa yang tertarik pada sampel uji (Ifriana, 2018; Zeniusa et al., 2019).

Hasil yang didapat pada variasi konsentrasi ekstrak batang akar kuning menunjukkan zona hambat terbesar yaitu pada konsentrasi $10 \%$ dengan nilai $9,18 \mathrm{~mm}$ terhadap bakteri Escherichia coli dan 12,16 $\mathrm{mm}$ terhadap bakteri Staphylococcus aureus, hal ini menunjukkan bahwa ekstrak akar kuning dapat menghambat bakteri Escherichia coli dengan kategori sedang, sedangkan terhadap bakteri Staphylococcus aureus dengan kategori kuat.

Menurut Christiani et al., (2015) apabila zona hambat yang terbentuk memiliki diameter 5-10 $\mathrm{mm}$ maka daya hambat bakteri sedang dan apabila zona hambat yang terbentuk 10-20 mm maka zona hambat bakteri tergolong kuat. Pada penelitian sebelumnya ekstrak etanol batang akar kuning (Fibraurea tinctoria Lour.) dengan konsentrasi $10 \%$ dapat menghambat bakteri dengan kategori sangat kuat terhadap bakteri Escherichia coli dan Staphylococcus aureus dengan nilai zona hambat sebesar 
20,8 $\mathrm{mm}$ dan 14,2 $\mathrm{mm}$ (Santoso et al., 2020).

Hasil pada penelitian ini memiliki nilai daya hambat yang berbeda dengan penelitian (Santoso et al., 2020) yang menyatakan nilai daya hambat ekstrak etanol akar kuning dalam kategori sangat kuat terhadap bakteri E. coli dan S. Aureus. Hal ini dikarenakan adanya perbedaan tempat lingkungan tumbuh, tekstur tanah pada tempat tumbuh tanaman serta dapat dipengaruhi oleh kecukupan unsur hara dalam tanah sehingga semakin banyak unsur hara yang terkandung dalam tanah maka senyawa metabolit yang terkandung dalam tumbuhan akan lebih baik dan kuantitas metabolit sekunder yang lebih banyak (Salim et al., 2017).

Terbentuknya zona hambat pada masing-masing variasi konsentrasi ekstrak diduga karena adanya senyawa aktif berupa senyawa metabolit sekunder yang terkandung dalam akar kuning. Pada penelitian (Supomo et al., 2020) akar kuning (Fibraura tinctoria Lour.) memiliki kandungan senyawa metobolit sekunder antara lain alkaloid, flavanoid, saponin dan terpenoid. Senyawa metabolit yang terkandung dapat mengham-bat pertumbuhan bakteri dengan cara merusak susunan dan menghambat sintesis pembentukan membran sel bakteri (Santoso et al., 2020).

Pada uji antibakteri fraksi n-heksan batang akar kuning (Fibraurea tictoria Lour.) hasil zona hambat yang terbentuk pada bakteri E. coli dan S. aureus tergolong sedang dengan nilai rata-rata zona hambat terbesar pada konsentrasi $10 \%$ terhadap bakteri $S$. aureus dengan nilai 7,96 $\mathrm{mm}$. Terbentuknya zona hambat pada perlakuan fraksi n-heksan diduga karena adanya senyawa alkaloid berberin dan terpenoid yang berhasil ditarik oleh pelarut $n$-heksan pada proses fraksinasi. Menurut Hanani (2015) alkaloid isoquinolin merupakan alkaloid dalam bentuk basa yang sifat kelarutannya dalam pelarut non polar sedangkan senyawa terpenoid merupakan komponen penting dari banyak ekstrak kayu yang diperoleh dengan pelarut non polar (Furi et al., 2015).

Akar kuning (Fibraurea tinctoria Lour.) mengandung senyawa berberin $25,8 \%$. Senyawa berberin merupakan salah satu jenis alkaloid isoquinolin yang berfungsi sebagai antivirus, antibakteri dan juga sebagai antiinflamasi (Roy et al., 2018).

Perbedaan kepekaan antara kedua bakteri uji pada penelitian ini dipengaruhi oleh perbedaan struktur membran sel bakteri, seperti jumlah peptidoglikan dan jumlah lipid, serta adanya enzim pendegradasi yang mampu memecah senyawa aktif yang ada dalam fraksi uji. $E$. coli mempunyai membran sel dengan kandungan lipid yang tinggi (11-22\%) dan struktur membran sel yang berlapis tiga (multilayer) yaitu lipoprotein, membran luar fosfolipid (lapisan dalam), dan lipopolisakarida (lapisan luar) tersusun atas lipid yang bersifat non polar. Senyawa aktif yang terkandung dalam fraksi uji memiliki sifat semi polar sehingga lebih mudah menembus lapisan peptidoglikan yang bersifat polar dari pada lapisan lipid non polar. Hal ini yang menyebabkan senyawa tersebut lebih sulit untuk masuk ke dalam membran sel bakteri E. coli, sehingga bakteri ini lebih tahan terhadap pengaruh fraksi uji. Selain itu bakteri E. coli memiliki membran luar fosfolipid yang berfungsi sebagai pertahanan selektif senyawasenyawa yang keluar atau masuk sel dan menyebabkan efek toksik, sehingga dapat mengurangi masuknya zat antibakteri ke dalam sel (Zeniusa et al., 2019).

Senyawa terpenoid menghambat pertumbuhan bakteri dengan mekanisme penghambatan terhadap sintesis protein, karena terjadinya penumpukan menyebabkan perubahan komponenkomponen penyusun sel bakteri itu sendiri. Senyawa terpenoid mudah larut dalam lipid sifat inilah yang mengakibatkan senyawa ini lebih mudah menembus dinding sel bakteri gram positif dan gram negatif (Sarfina et al., 2017)

Pada pengukuran diameter zona hambat ekstrak etanol dan faksi n-heksan batang akar kuning menunjukkan peningkatan zona hambat pertumbuhan bakteri yang terbentuk seiring kenaikan konsentrasi sediaan uji. Hal ini disebabkan semakin banyak senyawa aktif yang terkandung. Semakin tinggi konsentrasi maka zona hambat yang terbentuk akan semakin luas sehingga semakin banyak sel mikroba yang terhambat atau mengalami kematian sel (Ifriana, 2018). 
Pengujian antibakteri pada fraksi etilasetat didapatkan nilai rata-rata zona hambat paling besar yaitu $8,76 \mathrm{~mm}$ pada konsentrasi $5 \%$ terhadap bakteri $E$. coli dengan kategori sedang hal ini diduga karena adanya senyawa flavanoid yang berhasil ditarik oleh pelarut etilasetat dalam proses fraksinasi. Senyawa flavanoid merupakan senyawa yang berikatan dengan gula membentuk glikosida yang menyebabkan senyawa flavanoid lebih mudah larut dalam pelarut polar seperti etilasetat (Hanani, 2015).

Senyawa flavanoid memiliki aktivitas antibakteri yang baik karena adanya gugus fenol. Mekanisme kerja flavanoid sebagai antibakteri yaitu dengan pembentukan ikatan komplek fenol dengan DNA bakteri sehingga terjadi kerusakan permeabilitas dinding sel bakteri. Ikatan komplek yang terbentuk kemudian terurai dan menembus kedalam sel sehingga menyebabkan terjadinya koagulasi protein dan menyebabkan enzim bakteri tidak aktif sehingga membran sel bakteri tidak terbentuk dengan baik dan terjadi kebocoran sel bakteri yang menyebabkan bakteri mati (Sarfina et al., 2017).

Uji antibakteri pada fraksi sisa yang mengandung pelarut etanol dan air menunjukkan nilai zona hambat terbesar yaitu $13,71 \mathrm{~mm}$ pada konsentrasi 5\% terhadap bakteri $S$. aureus. Adanya aktivitas antibakteri yang terbentuk diduga karena adanya senyawa saponin dan flavanoid yang masih terkandung dalam fraksi sisa. Ekstrak batang akar kuning mengandung senyawa saponin ditandai dengan terbentuknya busa permanen $1,5 \mathrm{~cm}$ pada proses skrining fitokimia (Supomo et al., 2020). senyawa saponin merupakan senyawa yang ditemukan dalam bentuk glikosida yang memiliki sifat hodrofilik dan lipofilik serta senyawa ini mudah larut dalam air sedangkan pada senyawa flavanoid berikatan dengan glikosida sehingga mudah larut dalam pelarut polar (Hanani 2015; Nugroho, 2017).

Mekanisme kerja saponin sebagai antibakteri yaitu saponin memiliki molekul yang dapat menarik lemak dan molekul yang dapat menarik air sehingga saponin dapat menurunkan permukaan sel bakteri. Saponin berdifusi melalui membran luar dan dinding sel yang rentan, kemudian mengikat membran sitoplasma yang menyebabkan kurangnya kestabilan sel. Sitoplasma bocor keluar sel yang mengakibatkan kematian bakteri (Alfiah et al., 2015).

Hasil uji antibakteri pada fraksi sisa memiliki nilai zona hambat terbesar dibandingkan dengan fraksi n-heksan dan fraksi etilasestat, hal ini diduga karena dalam fraksi sisa banyak mengandung air yang lebih besar. Penggunaan etanol $70 \%$ dalam proses ekstraksi masih mengandung cukup banyak air yaitu $30 \%$ sehingga senyawa metabolit sekunder yang terkandung dalam batang akar kuning lebih cenderung larut dalam pelarut polar (Supriningrum et al., 2019). Hal ini sesuai dengan hasil uji sari larut ekstrak batang akar kuning menunjukkan bahwa ekstrak batang akar kuning yang terlarut dalam air memiliki nilai lebih besar $8,17 \%$ dari pada jumlah senyawa yang terlarut dalam etanol dengan nilai 6,69\% (Supomo et al., 2020). Penetapan kadar sari larut etanol dan air dapat memberikan gambaran awal jumlah kandungan senyawa kimia yang bersifat polar atau non polar yang dapat kita tarik dalam proses ekstraksi (Supriningrum et al., 2019).

Hal yang menarik pada hasil penelitian aktivitas antibakteri pada fraksi etil asetat dan fraksi sisa yaitu adanya hasil diameter zona hambat terbesar terdapat pada konsentrasi $5 \%$ dibandingkan $10 \%$. Penurunan diameter ini diduga disebabkan ketidakmampuan sampel uji melakukan difusi, tingginya konsentrasi menyebabkan sampel sulit untuk berdifusi secara maksimal kedalam medium inokulum, hal ini terjadi karena adanya kejenuhan sehingga senyawa aktif pada sampel tidak terlarut sempurna. Tingginya konsentrasi sampel tidak selalu menghasilkan diameter zona hambat semakin besar, hal ini dapat dipengaruh oleh beberapa faktor yang mempengaruhi aktivitas suatu senyawa aktif antimikroba selain senyawa aktif berdifusi di dalam media juga dipengaruhi oleh jumlah mikroba yang diujikan, kecepatan tumbuh mikroba uji, dan tingkat sensitifitas mikroba terhadap aktivitas senyawa aktif antimikroba (Erlyn, 2016).

Pengujian antibakteri pada penelitian ini menggunakan kontrol positif yaitu 
amoxi-cillin, amoxicillin merupakan antibiotik turunan amino penisilin yang bersifat bakterisidal yang dapat mengobati berbagai infeksi pada bagian kulit, telinga, saluran kemih, pneumonia, dan faringitis strepto-kokus yang disebabkan oleh bakteri Gram-negatif dan Gram positif. Pada penelitian ini menggunakan bakteri Escherichia coli dan Staphylococcus aureus yang merupakan bakteri gram negatif dan gram positif. Pemilihan jenis bakteri ini sesuai dengan kontrol positif yang digunakan yaitu anti-biotik yang bersifat sprektrum luas sehingga dapat menghambat pertumbuhan bakteri gram negatif dan gram positif.

Antibiotik merupakan senyawa kimia yang terbuat dari bakteri atau jamur yang memiliki kemampuan untuk menghambat pertumbuhan atau membunuh mikroorganisme (Maida, 2019).

Mekanisme kerja amoxicillin sebagai antibakteri yang bersifat spektrum yang luas yaitu mengikat enzim transpeptidase pada membran sitoplasma bakteri sehingga terjadi ketidakmampuan enzim mengkatalisis reaksi transpeptidasi dalam membentuk dinding sel, hal ini menyebabkan dinding sel yang terbentuk tidak sempurna, karena ketidaksempurnaan peptidoglikon yang terbentuk maka dinding sel bakteri mudah mengalami kerusakan (Pratiwi, 2017).

Berdasarkan hasil pengujian aktivitas antibakteri ekstrak etanol, fraksi n-heksan, fraksi etilasetat dan fraksi sisa batang akar kuning terhadap bakteri Escherichia coli dan Staphylococcus aureus dapat dilihat ekstrak etanol memiliki aktivitas antibakteri paling aktif kemudian diikuti fraksi sisa, fraksi etilasetat dan fraksi n-heksan. Dapat ditarik kesimpulan bahwa senyawa aktif batang akar kuning lebih banyak terlarut pada pelarut polar, hal ini dapat dilihat dari hasil rendemen pada fraksi sisa memiliki persentase rende-men lebih tinggi yaitu sebesar $84,4 \%$.

\section{KESIMPULAN DAN SARAN}

Berdasarkan hasil penelitian yang dilakukan dapat ditarik kesimpulan bahwa ekstrak etanol dan fraksi batang akar kuning (Fibraurea tinctoria Lour.) memiliki aktivitas antibakteri terhadap Escherichia coli dan Staphylococcus aureus serta pada fraksi sisa batang akar kuning memiliki aktivitas antibakteri paling kuat diantara fraksi lainnya.

Saran kepada peneliti selanjutnya untuk melakukan pengembangan sediaan antibiotik dari bahan alam serta dapat mengetahui struktur senyawa aktif batang akar kuning yang bersifat sebagai antibakteri.

\section{REFERENSI}

Alfiah, R., Rieska, K., \& Siti, M. (2015). Efektivitas Ekstrak Metanol Daun Sembung Rambat (Mikania micrantha Kunth) Terhadap Pertumbuhan Jamur Candida albicans. Journal Protobiont, $4(2), 52-57$.

Christiani, S., Fridayanti, A., \& Rusli, R. (2015). Aktivitas Antibakteri Ekstrak Akar Karamunting (Melastoma Malabathricum). 191-198. https:// doi.org/10.25026/mpc.v1i1.25

Erlyn, P. (2016). Efektivitas Antibakteri Fraksi Aktif Serai (Cymbopogon citratus) terhadap Bakteri Streptococcus mutans. Syifa, MEDIKA: Jurnal Kedokteran Dan Kesehatan, $\quad 6(2), \quad 111$. https://doi.org/10.32502/sm.v6i2.1387

Fahdi, F., Sari, H., Kesehatan, I., Husada, D., Besar, J., Deli, N., \& L, K. C. (2019). Uji Aktivitas Antibakteri Dari Ekstrak Etanol Daun Peria Laut ( Colubrina Asiatica L.) Terhadap Bakteri Staphylococcus Aureus Dan Esche-richia Coli The discovery of new antibiotic drugs is getting more and more reactive. The plant of the peria laut leaf. 2(1).

Furi, M., Mora, E., \& Zuhriyah. (2015). Isolasi dan Karakteristik Terpenoid dari Ekstrak Etil Asetat Kulit Batang Meranti Kunyit (Shorea conica). Jurnal Penelitian Farmasi Indoneisa, 3(2), 38-42.

Galappathie, S., Palombo, E. A., Yeo, T. C., Ley, D. L. S., Tu, C. L., Malherbe, F. M., \& Mahon, P. J. (2014). Comparative antimicrobial activity of South East Asian plants used in Bornean folkloric medicine. Journal of Herbal Medicine, 4(2), 96-105. https://doi.org/10.1016/j.hermed.2014. 03.001 
Hanani E.. (2015). Analisis Fitokimia. ECG: Jakarta

Ifriana, F. N., \& Kumala, W. (2018). Pengaruh ekstrak biji pala (Myristica fragrans Houtt) sebagai antibakteri terhadap pertumbuhan Pseudomonas aeruginosa. Jurnal Biomedika Dan Kesehatan, 1(3), 172-178. https://doi.org/10.18051/jbiomedkes.20 18.v1.172-178

Kaharap, A. D., Mambo, C., \& Nangoy, E. (2016). Uji efek antibakteri ekstrak batang akar kuning (Arcangelisia flava Merr.) terhadap bakteri Staphylococcus aureus dan Escherichia coli. Jurnal EBiomedik, 4(1). https://doi.org/ 10.35790/ebm.4.1.2016.12138

Kesehatan, K. (2013). Berita Neg. 1657, 158. www.djpp.kemenkumham.go.id

Maida S. \& Lestari K.A. (2019). Aktivitas Antibakteri Amoksisilin Terhadap Bakteri Gram Positif dan Bakteri Gram Negatif. Jurnal Pijar MIPA, 14 (3), 189-191.

Mujipradhana, V. N., Wewengkang, D. S., \& Suryanto, E. (2018). Aktivitas Antimikroba Dari Ekstrak Ascidian Herdmania Momus Pada Mikroba Patogen Manusia. Pharmacon, 7(3), 338-347.

https://doi.org/10.35799/pha.7.2018.20 601

Niasono A.B., Hadri L. Dan Triosono P., 2019, Resitensi Antibiotik Terhadap Bakteri Eschericia coli yang Diisolasi dari Peternakan Ayam Pedaging di Kabupaten Subang Jawa Barat, Jurnal Veteriner, 20 (2), 187-195.

noorcahyati, sulandjari, widyatmani sih dewi. (n.d.). at Samboja , East Kalimantan. 4.

Nugroho, A. (2017). Buku Ajar: Teknologi Bahan Alam. In Lambung Mangkurat University Press (Issue January 2017).

Petrovska, B. B. (2012). Historical review of medicinal plants' usage. Pharmacognosy Reviews, 6(11), 1-5. https://doi.org/10.4103/09737847.95849

Pratiwi, R. H. (2017). Mekanisme Pertahanan Bakteri Patogen Terhadap Antibiotik. Journal Pro-Life, 4(2), 418-429.
Rahmi, Y., Darmawi, D., Abrar, M., Jamin, F., Fakhrurrazi, F., \& Fahrimal, Y. (2015). Identifikasi Bakteri Staphylococcus Aureus Pada Preputium Dan Vagina Kuda (Equus caballus) (Identification of Staphylococcus aureus in Preputium and Vagina of Horses (Equus caballus)). Jurnal Medika Veterinaria, 9(2).

https://doi.org/10.21157/j.med.vet..v9i 2.3805

Roy, M., Liang, L., Xiao, X., Feng, P., Ye, M., \& Liu, J. (2018). Lycorine: A prospective natural lead for anticancer drug discovery. Biomedicine and Pharmacotherapy, 107(July), 615-624. https://doi.org/10.1016/j.biopha.2018.0 7.147

Salim, M., Yahya, Y., Sitorus, H., Ni’mah, T., \& Marini, M. (2017). Hubungan Kandungan Hara Tanah dengan Produksi Senyawa Metabolit Sekunder pada Tanaman Duku (Lansium domesticum Corr var Duku) dan Potensinya sebagai Larvasida. Jurnal Vektor Penyakit, 10(1), 11-18. https://doi.org/10.22435/vektorp.v10i1. 6252.11-18

Santoso, U., Utari, M., \& Marpaung, M. P. (2020). aktivitas antibakteri dan antijamur ekstrak btang akar kuning (Fibraurea chloroleuca Miers) terhadap Escherichia coli,Staphylococcus aureus dan Candida albicans. Jurnal Kesehatan Bakti: Jurnal Ilmu Keperawatan Analisis Kesehatan Dan Farmasi, 20, 194-208. https://www.ejurnal.stikesbth.ac.id/index.php/P3M_JKBTH/artic le/view/611

Sarfina, J., Nurhamidah, N., \& Handayani, D. (2017). Uji Aktivitas Antioksidan Dan Antibakteri Ekstrak Daun Ricinus communis L (Jarak Kepyar). Alotrop, l(1), 66-70. https://doi.org/10.33369/atp.v1i1.2725

Supomo, Hayatus S., Eka S.S., Kintoko dan Hardi A.W. (2020). Karakterisasi Parameter Spesifik dan Parameter Non Spesifik Akar Kuning (Fibraurea tinctoria). Jurnal Ilmiah Ibnu Sina, 5 (2), 416-425. 
Supriningrum, R., Fatimah, N., \& Purwanti, Y. E. (2019). Karakterisasi Spesifik Dan Non Spesifik Ekstrak Etanol Daun Putat (Planchonia valida). Al Ulum Jurnal Sains Dan Teknologi, 5(1), 6. https://doi.org/10.31602/ajst.v5i1.24 68

Tan, T. Y. C., Lee, J. C., Mohd Yusof, N. A., Teh, B. P., \& Syed Mohamed, A. F. (2020). Malaysian herbal monograph development and challenges. Journal of Herbal Medicine, 23(May 2018), 100380. https://doi.org/10.1016/ j.hermed.2020.100380

Tudjuka, K., Ningsih, S., \& Toknok, B. (2014). Keanekaragaman Jenis Tumbuhan Obat pada Kawasan Hutan Lindung di Desa Tindoli Kecamatan Pamona Tenggara Kabupaten Poso. Warta Rimba, 2(1), 120-128.
Utami, R., Fernando, A., Sari, I. P., \& Furi, M. (2017). Determination of berberine content of ethanol extract of root and stem of "sekunyit" (Fibraurea tinctoria Lour) using high performance liquid chromatography (HPLC) method. Jurnal Sains Farmasi \& Klinis, 3(2), 115-119. http://jsfkonline.org/index.php/jsfk/article/ view/84

Zalizar, L., Rahayu, I. D., Sujono, \& Nor, Y. A. (2019). Potency of Fibraurea tinctora Lour. extract as anti-bacterial agents towards pathogenic bacteria. IOP Conference Series: Earth and Environmental Science, 293(1). h https://doi.org/10.1088/17551315/293/1/012026

Zeniusa, P., Ramadhian, M. R., Nasution, S. H., Karima, N., Kedokteran, F., \& Lampung, U. (2019). Uji Daya Hambat Ekstrak Etanol Teh Hijau Terhadap Escherichia coli Secara In Vitro The Inhibition Test Of Green Tea Ethanol Extract On Escherichia coli IN. 8, 136-143. 